The temples are quadrangular structures enclosing one or more courts open to the sky, and they all agree in having the eastward side more or less north of east, the western side facing south of west. But the orientation varies considerably. Thus while the Temple of Ishtar is oriented almost due $\mathrm{N}$. and $\mathrm{S}$. and $E$. and W., facing only about $4^{\circ} \mathrm{N}$. of E., the Temple of Ninib faces about $20^{\circ} \mathrm{N}$. of E., and the Temple of Ninmakh some $25^{\circ} \mathrm{N}$. of $\mathrm{E}$. This latter temple has its entrance on the northerly side, and the shrine on the southern, whereas the Temple of Ishtar has entrances on the $E$. and $S$. sides, and the shrine on the W. The figures given are approximate only.

Dr. King is now at work on the third volume of his "History," each volume treating of a separate period, and being to some extent independent of the others. When completed the work will be of lasting value, although each year adds fresh knowledge from new discoveries. Dr. King teaches us much, but he also makes us feel how much there is to learn. What principles, for instance, guided the Babylonian architects and builders in the orientation of their temples?

June $\mathrm{I} 2$.

H. K.

\section{"Ptolemy's Catalogue of Stars."}

MAY I point out that your reviewer of "Ptolemy's Catalogue of Stars" (June I, p. 282) is mistaken in suggesting that a mere confusion between the uncial alpha $(=\mathrm{I})$ and the uncial delta $(=4)$ will account for Ptolemy's assignment of the first magnitude to what is now the third-magnitude star, $\theta$ Eridani?

The star, called "the last in the River," whence the Arabic name of Achernar, is expressly described in the catalogue as "brilliant," $\lambda a \mu \pi \rho$ ós, an epithet applied to no other in the group. And in another work of Ptolemy's, the \$áreıs, in which the risings and settings of thirty "fundamental" stars, fifteen of the first magnitude and fifteen of the second, are calculated for several parallels of latitude, "the last of the River" takes its place among those of the first magnitude.

Moreover, the same star is mentioned several times by Hipparchus in his one surviving work, the commentary on Aratus, and in each case it is described as the brightest in the constellation of the River, which it could not have been had it been of the fourth magnitude only.

Again, the star is of the first magnitude to Al Sûfi, whose catalogue was drawn up, 800 years after Ptolemy, for the express purpose of revising the magnitudes given in the Almagest. Al Sufi adds some particulars as to its position which alone would suffice to refute the wild suggestion that the star meant was, not $\theta$, but the modern $\alpha$ Eridani, Achernar, a star invisible to Greek and Arab astronomers.

There can be no reasonable doubt that $\theta$ Eridani has declined in lustre, from the first magnitude to the third, in the interval between Al Sûfi and the days when, during the early Portuguese voyages, it again was seen, after many centuries, by European eyes. That Ulugh Beg, I437, should still make it a first-magnitude star is remarkable, but not conclusive, as his work was a revision of the places only, not the magnitudes, assigned to the stars by his predecessors.

Noke, Islip, Oxford.

E. J. WEBB.

THE suggestion was not made by the reviewer, but is made in the work under review (p. I Io), where it is stated that "it is most probable that in a very NO. 2434, VOL. 97$]$ ancient manuscript the delta $=4$ was erroneously taken to be an alpha=I, of which the present investigation shows numerous examples." As regards the statements of Hipparchus, Ptolemy, and Sûfi, the facts are :-

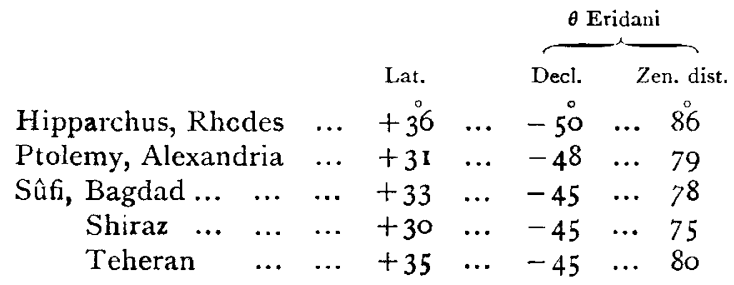

Suffi, on account of the low altitude, took the magnitude from Ptolemy. That $\theta$ Eridani was of the first magnitude for more than a thousand years, and from the time of Halley $(1677)$ to the present day of uniform brightness ( 3 or 4 mag.), without sign of variability, will scarcely be accepted by astronomers.

The Reviewer.

\section{Meteorological Conditions of a Blizzard.}

Your correspondents are entirely right in their contention that, in this country, the word "blizzard" is used as a rule quite wrongly. I have protested many times in the past against this misuse.

For various reasons, a true blizzard cannot occur in Britain. In the first place, as several correspondents have already pointed out, the necessary climatic conditions are lacking; for a wind of extremely high velocity never occurs here in conjunction with sufficiently intense cold, producing fine dry powdery driving snow. Secondly, a wind-velocity sufficiently high to produce a blizzard is seldom or never attained, except in a region marked by an immense extent of level surface, little broken by trees and other obstructions, and there is no such region in Britain. All the necessary conditions, both climatic and physical, exist, however, in that true home of the blizzard-the vast plains and prairies lying to the east of the Rocky Mountains, in Central North America, especially in Dakota and Manitoba. Even the great English snowstorm of January I8, I88I (which I remember very well indeed), bore little resemblance to a true blizzard, for the intense cold and high wind-velocity characteristic of a blizzard were both absent.

Those interested in the subject could not do better than refer to a little work, "Manitoba Described," which I published in 1885 , after a visit to that country. Therein will be found (pp. 57-58) an excellent description of a Manitoban blizzard, written by my friend Mr. Ernest Thompson Seton, then living there. It was, I believe, the earliest description ever published, at all events in this country. Moreover, its graphic style has never been, and could not be, excelled.

It may be worth mentioning-though the point is of etymological rather than of scientific interest-that the use of the word "blizzard" in the above-mentioned article (1885) marked, I believe, its first appearance in permanent literature in this country, though there are instances of its use three or four years earlier in English periodical literature. Earlier than that the word cannot have been used anywhere in the sense in question; for it did not make its appearance, even in American journalism, before the winter of $1880-81$.

Miller Christy.

Broom Wood Lodge, Chignal St. James, Chelmsford, June I3. 